\title{
Editorial
}

\section{Chegamos ao ISI! Mas quando realmente teremos nosso o primeiro Fator de Impacto e Índice de Imediatez?}

Caros Leitores,

É com grande satisfação que anunciamos a indexação em 2008 da Revista Brasileira de Farmacognosia (RBFAR) ao Institute for Scientific Information (ISI) órgão da empresa Thompson Scientific, que publica anualmente o Journal Citation Report (JCR) responsável pela divulgação do Fator de Impacto (FI) e Índice de Imediatez das revistas científicas. Este órgão representa um selo de qualidade das revistas científicas. Mas quando realmente a RBFAR terá seu primeiro fator de impacto e índice de imediatez ? É preciso que se entenda como esses índices são calculados. Por exemplo, o índice de imediatez mede a freqüência com que o artigo de um periódico é citado no mesmo ano de sua publicação, em outras palavras, o índice de imediatez determina a rapidez com que um artigo é lido e citado. $\mathrm{O}$ índice de ímediatez é calculado dividindo-se o total de citações num determinado ano para artigos publicados no mesmo ano pelo total de artigos publicados. Já o fator de impacto de uma revista é definido matematicamente como o número de vezes que os artigos das revistas são citados durante um período específico (o numerador), dividido pelo número total de artigos publicados por esta revista no mesmo período (denominador), num período convencional de dois anos.

Como o índice de imediatez mede a freqüência com que o artigo de um periódico é citado no mesmo ano de sua publicação, então, em 2009 quando o ISI publicar o índice de imediatez 2008, aparecerá um valor para RBFAR. Quanto ao Fator de Impacto, teremos que aguardar ainda dois anos. Como a RBFAR foi indexado ao ISI em 2008, então é preciso esperar até 2011, quando será publicado o FI de 2010, com as informações de citações que a revista recebeu em $2008+2009$. Portanto, em 2009 e 2010 aparecerá no Journal of Citation Report o nome da Rev. Bras. Farmacogn. = Braz. J. Pharmacogn., sem o fator de impacto (o local fica limpo, sem nenhum valor), quando for em 2011 aí sim é que teremos FI. Portanto, a partir de 2011 a RBFAR terá Fator de Impacto e Índice de Imediatez, simultaneamente.

Assim, queremos agradecer aos pesquisadores nacionais e internacionais que têm confiado seus ótimos artigos à nossa revista. Com o apoio destes e daqueles que citarem os artigos publicados na Revista Brasileira de Farmacognosia, estamos altamente otimistas para conhecer a partir de 2009 esses indicadores bibliométricos. Gostaríamos de agradecer também, em particular, os pareceristas, que fazem um trabalho silencioso, mas fundamental. Todos nós devemos celebrar esta conquista juntos!

Os Editores We've got to ISI! But when will we really have our first
Impact Factor and Immediacy Index?

Dear readers,

It is a great pleasure to announce the indexing in 2008 of the Brazilian Journal of Pharmacognosy (BJP) to the Institute for Scientific Information (ISI) agency of the firm Thompson Scientific, which annually publishes the Journal Citation Report (JCR) responsible for the dissemination of the Impact Factor (IF) and Immediacy Index of scientific journals. It represents a stamp of quality of scientific journals. But when will the BJP really have its first impact factor and immediacy index? We need to understand how these indices are calculated. For example, the immediacy index measures the frequency at which the article in ajournal is cited in the same year of its publication, in other words, the immediacy index determines the speed at which an article is read and cited. The immediacy index is calculated dividing the total citations in a given year for articles published in the same year by the total of published articles. The impact factor of a journal is mathematically defined as the number of times articles from journals are cited for a specific period (the numerator), divided by the total number of articles published by the journal in the same period (denominator), in a conventional period of two years.

As the immediacy index measures the frequency at which the article in a journal is cited in the same year of its publication, then in 2009 when the ISI publishes the immediacy index of 2008, there will be a value for the BJP. In relation to the impact factor, we must still wait two years. As the BJP has been indexed to the ISI in 2008, then it is necessary to wait up to 2011, when the IF of 2010 will be published, with information of the citations that the journal had received in $2008+2009$. Hence, in 2009 and 2010 the name of the Braz. J. Pharmacogn. = Rev. Bras. Farmacogn. will appear in the Journal of Citation Report, without the impact factor (the place is clean, without any value), thus we will have IF in 2011. So, from 2011 the BJP will have Impact Factor and Immediacy Index, simultaneously.

Therefore, we want to thank the national and international researchers who have been entrusting their excellent articles to our journal. With the support of these and of those who cite the articles published in the Brazilian Journal of Pharmacognosy, we are highly optimistic to know these bibliometric indicators from 2009. We would like also to thank in particular the referees, who make a silent, but essential work. All of us should celebrate this victory together!

The Editors 